\title{
Od maja 1968 do novembra 1989: Transformacije sveta, literature in teorije
}

Marko Juvan (Lublaň)

Mednarodna konferenca (ZRC SAZU, Ljubljana, 7.-8. 11. 2019), ki jo je v okviru raziskovalnega projekta o vlogi modernistične teorije in literature $\mathrm{v}$ študentskem gibanju »dolgega leta 1968 « (Robert Vinen) organiziral Inštitut za slovensko literaturo in literarne vede Znanstvenoraziskovalnega centra Slovenske akademije znanosti in umetnosti (gl. spletno stran https:// maj68.zrc-sazu.si/), je v preučevanje poskusa študentsko-delavske svetovne revolucije in njene usode v izteku 20. stoletja posegla z obravnavo dveh doslej zanemarjenih vidikov - literarnega in perifernega.

Ukvarjala se je z vprašanjem, kako sta bili kritična teorija in modernistična, neoavantgardna literatura povezani s protestništvom, ki se je zunaj okvirov institucionalizirane politike na prelomu iz šestdesetih $\mathrm{v}$ sedemdeseta leta 20. stoletja zavzemalo za družbeno-gospodarsko transformacijo tako kapitalističnega svetovnega sistema kakor njegove socialistične alternative. Dogajanja v Parizu (Debordova Situacionistična internacionala, Sollersov Tel Quel, francoski strukturalizem in poststrukturalizem) in drugih kapitalističnih metropolah so konferenčni referati primerjali s socialistično Ljubljano in drugimi mesti socialistične literarne polperiferije, med njimi tudi z Beogradom in Prago. Kot pričata npr. slovenska neoavantgardna skupina OHO s svojim konceptualizmom in land artom ter ljubljanska šola teoretske psihoanalize (Slavoj Žižek, Rastko Močnik, Zoja Skušek, Mladen Dolar idr.), ki je s strukturalistično formalizacijo marksizma vpeljala svetovno odmevni model lacanovske družbene kritike, so periferna okolja zaradi »imaginacijske bližine revolucije« (Perry Anderson) revitalizirala akademizirani ali komodificirani modernizem zahodnega jedra.

Ko se je z zlomom študentsko-delavskega gibanja v sedemdesetih letih iztekla zadnja faza literarnega modernizma, je nastopilo obdobje neoliberalne svetovne hegemonije. $\mathrm{V}$ jedrih svetovnega sistema sta sledila postmodernizem $\mathrm{v}$ estetiki in neokonservativizem $\mathrm{v}$ politiki. V Sloveniji in drugih jugoslovanskih republikah so zadnji sezoni modernizma $\mathrm{v}$ osemdesetih in devetdesetih letih sledili zlom samoupravnega eksperimenta, krvav razpad federacije in nastanek neodvisnih držav naslednic, ki jih je postopno kooptiral globalni kapitalizem. Posvet si je zastavil vprašanje, kako je leto 1968, ki mu je transformacija sveta dozdevno spodletela, privedlo do leta 1989, ki pa je svet transformiralo tako, da je razglasilo konec utopije, ki je navdihovala leto 1968.

Leto 89 je videti kot zrcalna slika leta 68. Ikonično postavljanje barikad v Parizu je nadomestil emblematičen padec berlinskega zidu. Nekdanji radikalni ideologi so se spremenili v »nove filozofe«, medtem ko so se revolucionarni yippiji preobrazili v yuppije. Nekdanji borci proti establišmentu so bili rekrutirani v nacionalne ali nadnacionalne politične elite. Neoliberalizem, ki se je pretvarjal, da je izpolnil zahteve študentov po individualnih svoboščinah in sprostitvi togih hierarhij, je razglasil zmago nad komunističnim totalitarizmom vzhodnega bloka, spodbudil gospodarsko rast s prilagodljivimi načini globalizirane proizvodnje ter razširil ideje človekovih pravic in kulturnih identitet po celem planetu. Zdi se, da je ta svetovni red v kali zatrl vsako alternativo, ki bi lahko črpala navdih iz spomina na maj 68. Toda Giovanni Arrighi, Terence K. Hopkins in Immanuel Wallerstein so že leta 1992 pokazali, da je leto 1989 tudi nadaljevanje leta 1968, »vaje« svetovne revolucije. Spontano vznikla gibanja postindustrijskega delavskega razreda in nove inteligence, ki so v šestdesetih letih »vadila" boj proti asimetrijam svetovnega sistema, nadaljujejo svoj spopad tudi okrog 
leta 1989, a ga prilagajajo propadu sovjetskega socializma, zatonu zahodne socialne države in premoči globaliziranih financ nad politikami nacionalnih držav.

Civilna družba osemdesetih let s svojimi ekološkimi, feminističnimi, LGBT, antirasističnimi in drugimi gibanji ne bi bila mogoča brez izkušenj dolgega leta 68. Prav tako ne bi mogli biti priča množičnim antiglobalističnim protestom novega tisočletja, kakršen je bil »Occupy Wall Street«. V kontrakulturi je pank radikaliziral uporništvo rokerjev prejšnje generacije. Na področju kulturne produkcije so bile post-avantgarde, kakršna je Neue Slowenische Kunst (NSK), neposreden odgovor na radikalizem njihovih neoavantgardnih predhodnikov. In končno ne more biti dvoma, da kritična teorija, s katero lacanovska »trojka" iz Ljubljane danes po svetovnih metropolah presoja globalna politična vprašanja, izhaja iz obrobnega intelektualnega laboratorija šestdesetih let.

Po uvodu vodje simpozija Marka Juvana, ki je orisal omenjeno problematiko, je Gáspár Miklós Tamás (Budimpešta) pokazal, da je študentskemu gibanju in kritični teoriji, ki je študente navdihovala, uspelo omajati konvencije buržoazne družbe, ni pa jima uspelo prevladati kapitalizma. Družbeno-zgodovinski kontekst od šestdesetih do osemdesetih let na Slovenskem sta osvetlila Lev Centrih (Koper) in Aleš Gabrič (Ljubljana). Medtem kot je med drugo svetovno vojno po Centrihu komunistični stranki uspelo povezati levičarske skupine v narodnoosvobodilni in revolucionarni projekt, ki mu je odprava kapitalizma sicer katastrofalno spodletela, pa so v osemdesetih letih disciplinirano stranko nadomestila pluralna civilnodružbena gibanja. Ta so sicer emancipirala le kritične intelektualce, na pa tudi delavstva in marginalnih skupin. V prvem primeru je teorija po Centrihu za svoj politični angažma plačala $\mathrm{z}$ lastno vulgarizacijo, v drugem pa z marginalizacijo. Gabrič je opozoril, da je bila Slovenija v šestdesetih letih tisti del komunističnega sveta, v katerem so se polemike med različno mislečimi lahko do neke mere odvijale javno. V osemdesetih letih se slovenski intelektualci, ki so leta 1968 prišli navzkriž z vlada- jočo stranko, na izkušnjo študentskega gibanja niso več dosti sklicevali, saj so v ospredje stopili drugi cilji, zlasti nacionalni.

Vlogo filozofsko-teoretskih koncepcij v dolgem letu 1968 je tematiziral Jernej Habjan (Ljubljana). Dialektično je pojasnil, zakaj kljub vplivnosti Sartrovega in Marcusejevega humanizma v študentskem gibanju in odsotnosti francoskih strukturalistov na protestih politika spomina na maj 1968 že pol stoletja kanonizira (post-) strukturalizem prav na račun humanizma. Odgovor je po Habjanu v vezavi Mao Tse Tunga na Marxa in Slavoja Žižka na Heideggerja. Nasprotno je Zdravko Kobe (Ljubljana) francoske strukturaliste in Lacana kritiziral, ker so se distancirali od revolucionarne akcije študentov oziroma se nanjo pripeli naknadno. Tako se je kritična teorija odtrgala od realnih razmerij in postala ideologija modernega srednjega razreda, medtem ko so boji za pravice izkoriščanih v nadaljnjih desetletjih ostali brez prave teorije. Emiliano Alessandroni (Urbino) je obravnaval idejo literature in njenega transformacijskega potenciala $\mathrm{v}$ delu pesnika in marksističnega intelektualca Franca Fortinija iz šestdesetih let. Dialektična ideja realnosti, ki je vodila Fortinijeve estetske sodbe, je učinkovala tudi v politiki (leta 1991 je Fortini posegel v polemiko o prvi zalivski vojni).

V študentskem gibanju je mogoče odkriti ne le izvore feminizma in ekologizma, ki sta zaznamovala civilnodružbena gibanja od osemdesetih let do danes, temveč tudi njihovega desničarskega antipoda - fašistoidnega populizma. Varja Balžalorsky Antić (Ljubljana) je pokazala, da je študentsko gibanje v Franciji sicer bilo pretežno moška zadeva, a se je na podlagah njegove decentrirane političnosti oblikovalo močno feministično krilo ter teorija in praksa écriture feminine. Neoavantgardne avtorice so po mnenju Balžalorsky Antić izkoristile družbeno-zgodovinsko konjunkturo, da so spolno stigmatiziranost preobrnile v emblem estetske inovacije in pridobile simbolno moč v literarnem sistemu. V Sloveniji se je feministično gibanje porodilo šele sredi osemdesetih let, torej s skoraj dvajsetletnim zamikom. Branislava Vičar (Maribor) je 
v pesniškem aktivizmu Jureta Detele od poznih šestdesetih let do pesnikove smrti leta 1992 odkrivala dosledno kritiko antropocentrizma in specizma, podprto s tenkočutno ekološko zavestjo. Na drugi strani je Branislav Jakovljevic (Stanford) opozoril na začetke nove desnice v Srbiji in Franciji okrog leta 1968 (Dragoš Kalajić, Julius Evola, Alain De Benoist); tedaj je bil diskurz desnice v Evropi eksces, a je danes prešel v manistream.

Premike, ki so se med letoma 1968 in 1989 dogajali na umetnostnem polju $\mathrm{v}$ Sloveniji in Jugoslaviji, sta obravnavala Miško Šuvaković (Beograd) in Lev Kreft (Ljubljana). Kreft je postsocialistično potrošništvo razlagal kot razvoj etike ugodja iz leta 1968. Po njegovem je odpor generacije 68 do nacionalnega kanona $\mathrm{v}$ osemdesetih letih zamenjal nasprotni projekt graditve nacionalne države. Slovenska alternativna kultura (zlasti NSK), nastala ob razpadanju socializma in Jugoslavije $\mathrm{v}$ kritični razdalji do omenjenih sprememb, je v širši regiji odigrala pomembnejšo vlogo od slovenske literature šestdesetih. Tudi Šuvaković je opozoril na estetske in politične razlike med kontekstom delovanja neoavantgardne skupine OHO iz šestdesetih let in retrogardnega gibanja Neue Slowenische Kunst (NSK) iz osemdesetih let. Skupina OHO je nastala na vrhuncu modernizma, kakršen se je razvijal v jugoslovanskem samoupravnem socializmu. Ta neovantgarda je delovala kritično in subverzivno v polju med pesniškim reizmom, arte povera, procesualno umetnostjo in konceptualizmom. Teoretsko so se oprli na Marcusejevo »novo senzibilnost«, strukturalizem in poststrukturalizem, a že tudi na new age. Gibanje NSK je nastalo sredi razpadanja socializma in v obdobju tranzicije. Izhajalo je z retrogibanj postmodernizma, sovjetskega socarta, panka in industrijskega roka. Transgresivne umetniške prakse je NSK radikaliziral z referencami na totalitarne režime; teoretsko zaledje si je našlo zlasti v ljubljanski šoli teoretske psihoanalize.

Več prispevkov je obravnavalo modernistične smeri v slovenski književnosti šestdesetih in sedemdesetih let. Njihova heterogenost je bila predmet natančne raziskave Irene Novak Po- pov (Ljubljana). Marijan Dović (Ljubljana) je predstavil reizem, smer v poeziji, prozi in likovni umetnosti, ki se je odrekla antropocentrizmu in raziskovala predmetni svet in naravo. Medtem ko je Darja Pavlič (Ljubljana) razložila poetiko ludizma, smeri, ki je umetnost utemeljila na načelih igre (mdr. tudi derridajevske igre označevalcev) in z njo izzivala vladajočo ideologijo ter rušila nacionalni kanon, pa je Kaitlyn Tucker (Chicago) opozorila na politične konflikte, ki jih je sprožil ta provokativni tok mlade literature. Andrej Tomažin (Ljubljana) je ob razcepu v reviji Problemi komentiral oddaljitev teoretske avantgarde ljubljanskih lacanovcev od literarno-umetniške avantgarde sredi sedemdesetih let. Razvoj protagonistov slovenskega eksperimentalnega gledališča šestdesetih let (Lado Kralj, Dušan Jovanović) v poznejše inovatorje osrednjih gledaliških institucij je zanimal Gašperja Troho (Ljubljana).

Mererid Puw Davies (London) je obravnavala zahodnonemško protestniško kulturo dolgega leta 1968, ki je segala od grafitov in letakov do agitpropovske poezije in avtobiografske proze. Bila je duhovita, provokativna, refleksivna ali napadalna. Opirala se je tako na avantgarde kakor na visoko literaturo, a je zaradi svojega antiliterarnega tona večinoma ostala nezanimiva za tradicionalno literarno vedo; ustrezala pa ji je tedanja (anti)literarna teorija, kakršno je razvijal Enzensberger. Charles Sabatos (Istanbul) je orisal obdobje »normalizacije« na Češkoslovaškem, kakor so ga tematizirali pisatelji, nagrajeni s srednjeevropsko literarno nagrado vilenica v Sloveniji. Obdobje med zasedbo Češkoslovaške leta 1968 ter žametno revolucijo leta 1989 je sicer zaznamovala represija, a je med drugim prineslo večje zanimanje za češko literaturo kakor katero koli obdobje prej ali potem. Romanopisci, nagrajeni z vilenico (Kundera, Moníková, Vilikovský in Topol), so reflektirali zgodovinsko izkustvo regije majhnih narodov, obdane s svetovnimi velesilami. Matteo Colombi (Leipzig) je primerjal češkoslovaška in jugoslovanska civilnodružbena gibanja med letoma 1968 in 1989 na primeru emancipacijske ideje paralelnega polisa (paralelni polis) češkega filozofa Václava Bende, ki je v osemdese- 
tih letih disidentskemu gibanju Listine 77 služil pri oblikovanju alternativnih družbeno-političnih struktur. Značilno se je tudi Benda po letu 1989 preusmeril v konservativno podpiranje lokalne različnosti in globalnega neoliberalizma.

Študentsko gibanje je postalo tema literature in kolektivnega spomina. Na ta vidik je v sklepu konference opozorila Alenka Koron (Ljubljana). Skozi prizmo odnosov med centrom in periferijo je štiri slovenske drame in pet romanov, napisanih med samim gibanjem ali po njem, razložila na sociokulturnem ozadju neuvrščene socialistične Jugoslavije in razčlenila njihove literarno-umetniške postopke.

\section{prof. Marko Juvan, PhD}

Inštitut za slovensko literaturo in literarne vede ZRC SAZU

Novi trg 2, p.p. 306, Ljubljana, SLO

mjuvan@zrc-sazu.si 